\title{
Message From the Editor-in-Chief
}

\author{
Hiroaki Shimokawa, MD, PhD
}

\section{Dear Colleagues}

On behalf of the Circulation Journal, I would like to let you know the 30 most frequently cited papers in the 17,368 papers previously published in the Japanese Circulation Journal (1968-2001)/Circulation Journal (2002-June 2011) (numbers in parentheses denote the number of citations).

1. (381) Matsuzawa Y, Nakamura T, Takahashi M, Ryo M, Inoue S, Ikeda Y, et al. New criteria for 'obesity disease' in Japan. Circ J 2002; 66: 987-992. (Review)

2. (250) Kitabatake A, Inoue M, Asao M, Tanouchi J, Masuyama T, Abe H, et al. Transmitral blood flow reflecting diastolic behavior of the left ventricle in health and disease: A study by pulsed doppler technique. Jpn Circ J 1982; 46: 92102.

3. (209) Ryo M, Nakamura T, Kihara S, Kumada M, Shibazaki S, Takahashi M, et al. Adiponectin as a biomarker of the metabolic syndrome. Circ J 2004; 68: 975-981.

4. (167) Hamano K, Nishida M, Hirata K, Mikamo A, Li TS, Harada M, et al. Local implantation of autologous bone marrow cells for therapeutic angiogenesis in patients with ischemic heart disease: Clinical trial and preliminary results. Jpn Circ J 2001; 65: 845-847.

5. (142) Kawai S, Suzuki H, Yamaguchi H, Tanaka K, Sawada H, Aizawa T, et al. Ampulla cardiomyopathy ('Takotsubo' cardiomyopathy): Reversible left ventricular dysfunction with ST segment elevation. Jpn Circ J 2000; 64: 156-159.

6. (136) Aoki K, Yamori Y, Ooshima A, Okamoto K. Effects of high or low sodium intake in spontaneously hypertensive rats. Jpn Circ J 1972; 36: 539-545.

7. (123) Ueyama T, Kasamatsu K, Hano T, Yamamoto K, Tsuruo Y, Nishio I. Emotional stress induces transient left ventricular hypocontraction in the rat via activation of cardiac adrenoceptors: A possible animal model of 'tako-tsubo' cardiomyopathy. Circ J 2002; 66: 712-713.

8. (116) Yamori Y, Nagaoka A, Okamoto K. Importance of genetic factors in stroke: An evidence obtained by selective breeding of stroke-prone and -resistant SHR. Jpn Circ J 1974; 38: 1095-1100. (Review)

9. (115) Kawai C. Idiopathic cardiomyopathy: A study on infectious-immune theory as a cause of disease. Jpn Circ J 1971; 35: $765-770$.

10. (113) Ehara M, Surmely JF, Kawai M, Katoh O, Matsubara T, Terashima M, et al. Diagnostic accuracy of 64-slice computed tomography for detecting angiographically significant coronary artery stenosis in an unselected consecutive patient population: Comparison with conventional invasive angiography. Circ J 2006; 70: 564-571.

11. (108) Yamori Y. Pathogenesis of spontaneous hypertension as a model for essential hypertension. Jpn Circ J 1977; 41: 259-266. (Review)

12. (98) Tanase H, Suzuki Y, Ooshima A, Yamori Y, Okamoto K. Genetic analysis of blood pressure in spontaneously hypertensive rats. Jpn Circ J 1970; 34: 1197-1212.

13. (90) Matsuzaki M, Kita T, Mabuchi H, Matsuzawa Y, Nakaya N, Oikawa S, et al. Large scale cohort study of the relationship between serum cholesterol concentration and coronary events with low-dose simvastatin therapy in Japanese patients with hypercholesterolemia: Primary prevention cohort study of the Japan Lipid Intervention Trial (J-LIT). Circ J 2002; 66: $1087-1095$.

14. (85) Sekiguchi M, Numao Y, Imai M, Furuie T, Mikami R. Clinical and histopathological profile of sarcoidosis of the heart and acute idiopathic myocarditis: Concepts through a study employing endomyocardial biopsy: I. Sarcoidosis. Jpn Circ J 1980; 44: 249-263.

15. (82) Amano S, Hazama F, Hamashima Y. Pathology of Kawasaki disease: I. Pathology and morphogenesis of the vascular changes. Jpn Circ J 1979; 43: 633-643.

16. (80) Owa M, Aizawa K, Urasawa N, Ichinose H, Yamamoto K, Karasawa K, et al. Emotional stress-induced 'ampulla cardiomyopathy': Discrepancy between the metabolic and sympathetic innervation imaging performed during the recovery course. Jpn Circ J 2001; 65: 349-352.

(80) Kawamura K, Kashii C, Imamura K. Ultrastructural changes in hypertrophied myocardium of spontaneously hypertensive rats. Jpn Circ J 1976; 40: 1119-1145. 
18. (78) Yamaguchi T, Minematsu K, Choki J, Ikeda M. Clinical and neuroradiological analysis of thrombotic and embolic cerebral infarction. Jpn Circ J 1984; 48: 50-58.

(78) Yasue H, Omote S, Takizawa A, Nagao M, Miwa K, Kato H, et al. Pathogenesis and treatment of angina pectoris at rest as seen from its response to various drugs. Jpn Circ J 1978; 42: 1-10.

20. (77) Komachi Y, Iida M, Shimamoto T, Chikayama Y, Takahashi H, Konishi M, et al. Geographic and occupational comparisons of risk factors in cardiovascular diseases in Japan. Jpn Circ J 1971; 35: 189-207.

(77) Yamori Y, Matsumoto M, Yamabe H, Okamoto K. Augmentation of spontaneous hypertension by chronic stress in rats. Jpn Circ J 1969; 33: 399-409.

22. (74) Ogura R, Hiasa Y, Takahashi T, Yamaguchi K, Fujiwara K, Ohara Y, et al. Specific findings of the standard 12-lead ECG in patients with 'Takotsubo' cardiomyopathy: Comparison with the findings of acute anterior myocardial infarction. Circ J 2003; 67: 687-690.

(74) Shimokawa H. Cellular and molecular mechanisms of coronary artery spasm: Lessons from animal models. Jpn Circ J 2000; 64: 1-12. (Review)

24. (73) Ishikura K, Yamada N, Ito M, Ota S, Nakamura M, Isaka N, et al. Beneficial acute effects of Rho-kinase inhibitor in patients with pulmonary arterial hypertension. Circ J 2006; 70: 174-178.

(73) Hori M, Yelin EL, Sonnenblick EH. Left ventricular diastolic suction as a mechanism of ventricular filling. Jpn Circ J 1982; 46: 124-129. (Review)

26. (71) Ichijima K. Morphological studies on peripheral small arteries of spontaneously hypertensive rats. Jpn Circ J 1969; 33: $785-813$.

27. (70) Kodama K, Sasaki H, Shimizu Y. Trend of coronary heart-disease and its relationship to risk-factors in a Japanese population: A 26-year follow-up, Hiroshima/Nagasaki study. Jpn Circ J 1990; 54: 414-421.

28. (69) Yoo TW, Sung KC, Shin HS, Kim BJ, Kim BS, Kang JH, et al. Relationship between serum uric acid concentration and insulin resistance and metabolic syndrome. Circ J 2005; 69: 928-933.

29. (66) Fontaine G, Frank R, Tonet JL, Guiraudon G, Cabrol C, Chomette G, et al. Arrhythmogenic right ventricular dysplasia: A clinical-model for the study of chronic ventricular-tachycardia. Jpn Circ J 1984; 48: 515-538. (Review)

30. (63) Kurisu S, Inoue I, Kawagoe T, Ishihara M, Shimatani Y, Nakamura S, et al. Time course of electrocardiographic changes in patients with tako-tsubo syndrome: Comparison with acute myocardial infarction with minimal enzymatic release. Circ J 2004; 68: 77-81.

The Editorial Team looks forward to receiving manuscripts with high scientific impact from all over the world.

Hiroaki Shimokawa, MD, $\mathrm{PhD}$

Editor-in-Chief

Circulation Journal

(Released online July 21, 2011) 